\title{
SOCIAL EVALUATION OF PUBLIC UTILITY SERVICES IN THE DOWNTOWN RESIDENTIAL AREA OLD TOWN IN SZCZECIN (POLAND)
}

\author{
KATARZYNA TOWPIEKO,${ }^{1}$ NATALIA SYPION-DUTKOWSKA ${ }^{2}$
}

University of Szczecin, Faculty of Geosciences, POLAND

${ }^{1}$ e-mail: k.towpieko@wp.pl

2 e-mail: natalia.sypion@usz.edu.pl

\section{RECEIVED \\ ACCEPTED \\ JEL \\ CLASSIFICATION}

KEYWORDS

ABSTRACT
10 December 2018

28 December 2018

$\mathrm{H} 4, \mathrm{P} 36, \mathrm{R} 23$

cities, neighbourhoods, public services, social evaluation, downtown residential areas, Szczecin

The term "services" is defined in a variety of ways, depending on the research approach. Among service activities, a special role is played by public services located in downtown residential areas. They constitute a specific mix of various types of private and public activities, which provide tangible and intangible goods to the inhabitants of this area, who use them constantly or frequently, but also citywide services, which are used by all inhabitants of the city. The basic aim of this article is to determine the opinion of inhabitants about the services located in the downtown residential area Old Town in Szczecin. Based on the survey, the type of public services used by inhabitants and people outside this area was specified. Moreover, an assessment was made as to whether there is a sufficient number of services in the given area and evaluation of their burdensomeness.

\section{Introduction}

In economic research, more and more often attention is put on the causal links between service activities and an area. There can be noticed spatial differentiation in the level of consumption or provision of services. Services are located mostly proportionally to the population distribution. The basic condition for the optimal performance 
of the national economy is the level of development of the given area. It is very important to create conditions for the efficient functioning of production in a given area, as well as the welfare of the population, i.e. the service function.

\section{Literature review - Services consumed by persons (B2C)}

S. Balin and V. Giard (2006) reviewed numerous definitions of services presented in the world literature. Polish publications also present a wide variety of approaches and definitions. J. Chmielewski (2001, p. 176) believes that services are the third sector of human economic activity. They aim at meeting social, material and non-material needs, which are constantly increasing. Services can be provided at the level of family life, by citizens for the benefit of others and by public institutions.

According to K. Kłosiński (as cited in: Inicki, 2009, p. 30), services are activities whose effect is to satisfy the specific needs of an entity, be it a person, company, commune, city or country.

F. Kłosowski (as cited in: Inicki, 2009, p. 29) described the essence of services as all institutional activities aimed at an entity - which may be a person, an enterprise or a thing - in order to give, preserve or restore a new or existing value that does not provide a material product.

An original and different definition of services was formulated by K. Rogoziński (as cited in: Inicki, 2009, p. 29). According to this definition, the service, in addition to its other features, is commissioned and consumed by specific individuals before the service system develops. A service is commissioned provision of work and benefits to enrich personal qualities or the volume of use values that the recipient has. The author of this definition treats services as not only a supplement to the basic manufacturing activity of industry, but also as satisfying one's important and specific needs.

Individual services and those that result from the functions of the state (health care, social welfare, education, defense, public administration and others) are non-market services (Stefaniak, 2007, p. 99). The result of the nonmarket activities is free or partly paid. There is a consensus that market services are activities governed by market mechanisms, and their result, in the form of goods, is acquired from personal income (Ilnicki, 2009). These services play a significant role in the socio-economic life and spatial development of cities, as well as largely shape the level and quality of life of its inhabitants (Dzieciuchowicz, 2006).

J. Chmielewski (2001, p. 178) divided service facilities and institutions into two groups. The first includes social-type services, which are an indispensable part of the municipal infrastructure of the city. These services are protected by the state and local governments, and are founded from local or government budgets. This group includes education, culture, upbringing, leisure, health and social care, and administration. The second group comprises commercial facilities and institutions. Their standard, locations and impact zone are defined by the market. They include, among others, commerce, catering, living services, communications, automotive facilities and entertainment. When taking into consideration the purpose, there can be distinguished production, consumer and general social services. Production services are related to the production of material goods, e.g. electricity distribution. Individual and collective consumers use consumer services, e.g. transport, commerce, science, culture and hairdressing. General public services include, among others, public safety and public administration (Panasiuk, Tokarz, 2005, pp. 41-42). 


\section{Method}

The study was conducted using the direct interview method among 100 respondents (50 inhabitants of the Old Town in Szczecin and 50 people not living in the Old Town). 50 women and 50 men participated in the study. The average duration of an interview was about five minutes. The survey was conducted at three different times of the day, from $10.00-12.00,14.00-16.00$ and after 18.00 . The elderly were interviewed mainly in the morning hours. Most people who did not live in the Old Town were met during the weekend and were usually aged 26-65.

\section{Results}

The educational background of the survey participants shows that the dominant group consisted of respondents with secondary education (40\%). These are mainly working people and pensioners. People with higher education accounted for $29 \%$ of the sample. Respondents with primary education constituted only $15 \%$ of the sample (pupils), whereas $16 \%$ were people with vocational education.

As far as professional status is concerned, in the structure of participants it can be observed that working respondents (54\%) are dominant. There were interviewed $14 \%$ of the pupils and students, $13 \%$ of pensioners, and only $5 \%$ of the unemployed.

\section{Overall assessment of existing public sepvices}

The respondents could choose four responses regarding the quality of services located in the Old Town of Szczecin. They could assess, at their own discretion, the quality of services as "very good", "good", "average" or "poor". The respondents were to assess the quality of services located in the Old Town, including cultural, entertainment, educational/school system, health care, public administration, sports and numerous tourist services. 47 people assessed the services as "good", 28 as "very good", while 21 respondents chose "average". None of the respondents rated the quality of services located in the Old Town as "poor". One person out of twenty-five surveyed did not answer this question, as they do not use services located in the area.

\section{Services for inhabitants}

Services for inhabitants include, inter alia, health care, numerous grocery stores, churches, kindergartens, schools, vegetable and fruit kiosks.

All interviewees declared that they use services located in the Old Town. It can be seen that most people use commercial services - this answer was chosen by as many as 39 respondents. As many as 35 inhabitants willingly use catering services, and 28 respondents enjoy financial services such as banks. 22 respondents use cultural services, such as the Museum of Contemporary Art at Żołnierza Polskiego square, the National Museum in Szczecin at Staromłyńska Street, and the Castle Museum at Korsarzy Street. This answer was chosen mainly by working people with secondary and higher education. The hairdresser and cosmetic services are used by 19 inhabitants. 18 respondents use health care services, whereas 16 inhabitants chose entertainment services and 11 public administration services. Educational and school system as well as sports services were chosen by 9 respondents. The services that were the least frequently chosen are: tourist services (8 people), repairs such as shoemaker, computer and bicycle services (9 people). Only 4 people wrote "the church" in the "other" section, i.e. they use sacred services. 
Women more frequently use the services of culture, gastronomy, commerce and health care, hairdresser and beautician, whereas men more willingly chose sports, entertainment and financial services. The inhabitants use services located in the Old Town mainly several times a week (39 people). 8 respondents use services located in the area every day; 2 respondents once a week; and 1 person several times a month.

When using services in the Old Town, the inhabitants are mainly driven by their place of residence (48 people) and location (17 people). Less popular was the price ( 8 people), the prestige of the place ( 5 people) and the place of work (3 people).

\section{Services for tourists}

People from outside of the Old Town are more willing to use tourist services. They visit the Old Town mainly at weekends to meet friends and try catering services. Young people attend schools that are located in the Old Town. University students often visit the Pomeranian Library.

Out of 50 people questioned from outside of the Old Town, 6 respondents declared that they do not use services located in the area. Most respondents use commercial services (28 people) and catering services (23 people). 17 people use tourist services. The Old Town is an attractive place for people who like to visit the historical sites of the city. Financial services are used by 13 respondents, entertainment services by 12 respondents, and education services by 11 respondents. The less frequently chosen services include: cultural (7 people), sports (4 people), hairdresser/ beautician (4 people), health care (3 people), and public administration services (3 people). The service most rarely chosen was repairs, for example, shoemaker, computer and bicycle services; this answer was chosen by every 25 th respondent. Young people more often choose entertainment services. On the other hand, working people willingly use catering, commercial, financial and tourist services.

People from outside of the Old Town use services in a given area mainly once a week (17 people) and several times a month (11 people). 9 people use the services located in the area of the Old Town several times a week, 4 people once every six months, and 3 people once a month. Only 6 people replied that they do not use the services in the Old Town.

When using services in the studied area, people from outside of the Old Town are driven mainly by the location (28 people) and the prestige of the place (11 people). Every 10th person uses services in a given area because of the place of work. The smallest number of people use the services located in the Old Town due to prices (4 people) and the place of residence (two people). The "other" answer was indicated by 6 respondents. One person uses services in the Old Town due to the popularity of the place, two people attend schools in the area, and two people visit their family there.

\section{Desired and undesired services}

All respondents were asked the question: "Is there enough services in the Old Town?". The respondents could choose four answers (yes, no-there are not enough of them, there are too many of them, I have no opinion). Most respondents believe that there are enough services in the Old Town (76\%). Only $8 \%$ of respondents said that there are too many services. $7 \%$ think that there are not enough services in the Old Town, and $9 \%$ of respondents have no opinion.

To sum up, it can be stated that majority of respondents think that there are enough services in in the Old Town. More people living in the analysed area than people from outside of the area recognized that there are not 
enough services. There is mainly a lack of services for pensioners. The Old Town is inhabited by a large number of retirement-aged people, who use mainly commercial and sacred services. The rest of the interviewees gave their individual preferences, such as a football pub or a health food market. People who think that there are too many services have in mind mainly restaurants, which according to them are in abundance in some parts of the Old Town. In their opinion, this is associated with parking and noise problems.

\section{Burdensomeness of services}

A group of a hundred people were asked if the services located in the Old Town are burdensome. According to $68 \%$ of respondents, services located in the Old Town are not burdensome. $6 \%$ think they are burdensome, and $26 \%$ of respondents have no opinion on this subject. Of no opinion were mostly people living outside the Old Town. They were not able to comment on this subject, as some of them rarely use services in the area.

The majority of inhabitants, i.e. 36 people ( $72 \%$ of the total number), believe that services located in the Old Town are not burdensome. 8 people ( $16 \%$ of the total population) do not have any opinion about the burdensomeness of the services. Only 6 people think that services in the given area are burdensome by mainly indicating restaurants and pubs. The inhabitants are tired of noise made by moving tables in front of the restaurants and loud conversations of people leaving pubs in the evening. Moreover, the problem for them is parking, mainly at weekends, when people from outside of the Old Town are more willing to use catering services.

\section{Conclusions}

Today, the Old Town is a specific residential area of Szczecin. It covers the oldest part of the city, which for many years has changed its infrastructure and image due to wars and various architectural concepts. This residential area shapes the city's image and attracts tourists. It is dominated by multi-family residential units with related services and service development area. It includes, among others, numerous services of culture, catering, commerce and tourism. The area is inhabited by working and post-working age population. This is due to the fact that after settling down and finishing their education, etc., people more and more often decide to live outside the city centre. They choose more favourable locations that offer better housing conditions. The respondents, who know the studied area well, often mentioned the large throughput of homeless people and the lack of sufficient number of police patrols.

Most respondents are aged 36-65, have secondary education and are mainly working people. The most popular services are commercial, catering and financial services. The reason for this may be that this area offers the greatest number of such services. Moreover, cultural and entertainment services are popular. Most respondents believe that there are enough services in the Old Town. Inhabitants of the Old Town in the post-productive age lack places designed just for them. Senior clubs or places where the elderly can share their life wisdom and experience can be created there. Four inhabitants of the Old Town said that there are too many services in the area. According to six inhabitants, restaurants and pubs are bothersome. They also stated that they have problems with parking during the weekend. People from outside of the Old Town were more likely to have no opinion on the given topic. None of the people living outside of the Old Town has found services burdensome. Only three people who live outside the given residential area believe that there are not enough services. They exchanged services that interest them the most, e.g. a football pub. The inhabitants of the studied area use the services mainly a few times a week, and are mainly driven by the place of residence. People from outside of the residential area use services in the 
area less frequently, mainly thanks to the location and prestige of the place. The service quality was evaluated as "good". The inhabitants of the Old Town were more critical and more frequently described the quality of services as "average". People living in the area had no problems with answering the questions, only a few people from outside of the Old Town did not respond because they do not use the services.

Women more frequently use the services of culture, gastronomy, commerce and health care, hairdresser and beautician. Men more willingly chose sports, entertainment and financial services. Women and men are eager to use gastronomy and commercial services. Women more willingly answered the questions, however they were more critical about the quality of service. Pupils and students are satisfied with the quality of services. This may be due to the fact that the area includes the Pomeranian Library and numerous restaurants and pubs.

\section{References}

Balin, S., Giard, V. (2006). A process oriented approach to the service concepts. IEEE_SSSM06 Conference. Retrieved from: https:/l www.lamsade.dauphine.fr/ giard/IEEE_SSSM06_Giard_Balin.pdf.

Chmielewski, J. (2001). Teoria urbanistyki w projektowaniu i planowaniu miast. Warszawa: Oficyna Wydawnicza Politechniki Warszawskiej.

Dzieciuchowicz, J. (2006). Usługi nierynkowe w przestrzeni miejskiej Łodzi. Łódź: Wydawnictwo Uniwersytetu Łódzkiego.

IInicki, D. (2009). Przestrzenne zróżnicowanie usług w Polsce: teoretyczne i praktyczne uwarunkowania badań. Wrocław: Instytut Geografii i Rozwoju Regionalnego Uniwersytetu Wrocławskiego.

Panasiuk, A., Tokarz, A. (2005). Specyfika i klasyfikacja usług. In: S. Flejterski (ed.), Współczesna ekonomika usług (pp. 41-45). Warszawa: Wydawnictwo Naukowe PWN.

Stefaniak, J. (2007). Rola usług w gospodarce. In: D. Kopycińska (ed.), Zachowania rynkowe w teorii i praktyce (pp. 98-107). Szczecin: Katedra Mikroekonomii Uniwersytetu Szczecińskiego.

Cite this article aS: Towpieko, K., Sypion-Dutkowska, N. (2018). Social evaluation of public utility services in the downtown residential area Old Town in Szczecin (Poland). European Journal of Service Management, 4 (28/2), 505-510. DOI: 10.18276/ejsm.2018.28/2-61. 